https://doi.org/10.24101/logos.2019.04

Gauta 20190212

\title{
LINA VIDAUSKYTÉ
}

Vilniaus universitetas, Lietuva

Vilnius University, Lithuania

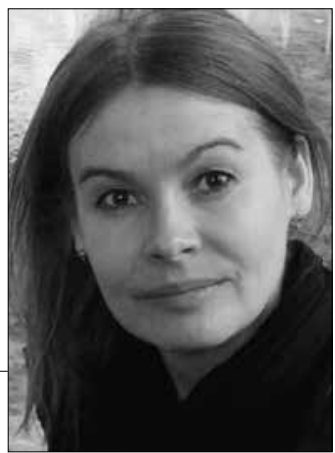

\section{MITAS IR ŠIFRAS. POSTSEKULIARYBE்S IMPLIKACIJOS KARLO JASPERSO IR RUDOLFO BULTMANNO MĄSTYME'}

\author{
Myth and Cipher. The implications of Post-secularity \\ in the Thinking of Karl Jaspers and Rudolf Bultmann
}

\section{SUMMARY}

The article is focused on the famous discussion between philosopher K. Jaspers and theologian R. Bultmann on demythologization of Christianity. The main points of the discussion, the arguments put forward by both sides, and the proposed alternative to the program of demythologization offered by Jaspers are outlined. Demythologization of Christianity indicates the religious crisis and an attempt to overcome it. For Bultmann, the development of modern science is incompatible with the mythical picture of the Christian religion. Therefore, he announces the program of demythologization and seeks to introduce an existential analysis of the New Testament. M. Heidegger's philosophy should have been the basis for this existential analysis. The author asks the question of whether it is possible to overcome myths in general. In fact, this is not only a personal view of Jaspers, but a philosophical position shared by philosophers Hans Blumenberg and Odo Marquard.

\section{SANTRAUKA}

Straipsnyje analizuojama filosofiniu ir religiniu požūriu reikšminga filosofo K. Jasperso ir teologo R. Bultmanno diskusija krikščionybès numitinimo klausimu. Išskiriami svarbiausi diskusijos momentai, abiejų dalyvių išsakyti argumentai bei pristatoma Jasperso pasiūlyta alternatyva numitinimo programai. Krikščionybės numitinimas sykiu byloja apie religijos krizę ir bandymą ją jeveikti. Bultmanno įsitikinimu, modernaus mokslo raida yra nesuderinama su mitiniu krikščioniškosios religijos pasaulèvaizdžiu. Jis skelbia numitinimo programą ir siekia įtvirtinti egzistencinę Naujojo Testamento interpretaciją. Šios analizès pagrindu turèjo tapti M. Heideggerio filosofija. Straipsnyje keliamas klausimas, ar mitą apskritai yra įmanoma jiveikti. 


\section{POSTSEKULIARYBE், RELIGIJOS KRIZĖ IR KRIKŠČIONYBĖS NUMITINIMAS}

Palyginti neseniai isitvirtinusi postsekuliarybés sąvoka vis dar vartojama gana laisvai ir nèra visuotinio sutarimo, ką ji tiksliai reiškia. Nors priešdèli "post-“ galima būtų traktuoti kaip tam tikrą chronologinę nuoroda, tačiau vis dar nèra aišku, kokios galètų būti postsekuliarybès chronologinès ribos, t. y. kokie „dvasiniai įvykiai“ čia galètų būti laikomi riboženkliais. Aišku tik tiek, kad postsekuliarybè susijusi su tuo, jog nunyko besąlygiškas pasitikèjimas Apšvietos epochos mąstytojų šlovinta žmogaus proto galia, neva turejjusia galutinai išsklaidyti „religinius prietarus", sukurti sekuliarią kultūrą ir tuo būdu užtikrinti vien protu grindžiamą žmonijos pažangą. Toks pasitikèjimo protu nunykimas reiškè, kad šiuolaikinis pasaulis išgyvena gilią gyvenimo pagrindo trūkumo krizę.

Tačiau sykiu tapo aišku, kad neįmanoma tiesiog restauruoti presekuliarios būklès, kai religiniai vaizdiniai, religinès doktrinos bei praktikos teikė žmogui besąlygišką pamata, kad tenka gyventi "sekuliariame mieste" (Cox 2013) arba „sekuliariame amžiuje“ (Taylor 2007).

Viena pagrindinių krizès apraiškų šiuolaikineje epochoje yra tradicinių religinių vaizdinių ir modernaus mokslo pateikiamo pasaulèvaizdžio neatitikimas. Siekiant izveikti ši neatitikima, buvo siūlomi įvairūs sprendimai, vienas kurių buvo krikščionybès „numitinimo“ ideja, pirmiausia siejama su vieno iškiliausių XX a. protestantų teologo Rudolfo Bultmanno vardu.

Bultmannas pasiūlè egzistencinę Naujojo Testamento interpretacija, kurios pamatą sudarè Martino Heideggerio veikale Sein und Zeit (1927) išplètota egzistenciné filosofija. Joje Bultmannas surado sąvokas, kurios leido adekvačiai kalbèti apie žmogaus egzistencija, vadinasi, apie tikinčio žmogaus egzistenciją. Bultmannas organiškai įkomponavo Heideggerio filosofijos sąvokini aparatą tiek $\mathfrak{i}$ savo plètojamą kerigmos teologija, tiek i numitinimo bei egzistencinès interpretacijos programą.

Bultmannas Biblijos kritiką mūsų amžiuje laiko neišvengiama, o ši kritika susijusi su tuo, kad krikščioniškojo tikèjimo mokymas Biblijoje yra išdèstytas mitologine forma. Apskritai visas biblinis pasaulio vaizdas yra mitologinio pobūdžio. Idomu tai, kad iš tiesų užuot pateikęs formalų mito apibrèžimą, Bultmannas pabande išryškinti pasenusią mitinès pasaulèvokos sistemą. Šią pasaulèvoką jis apibūdina kaip bandymą antgamtinių jègu i̊sikišimu paaiškinti viska, kas yra neịprasta ir kelia nuostabą. Todèl Bultmannas ir kelia sau uždavini Naujojo Testamento pasauli numitinti. Jo teigimu, tas pasaulis yra padalintas $i$ tris aukštus: viduryje yra Žemè, virš jos Dangus, o apačioje - Pragaras. Danguje gyvena Dievas ir dangaus būtybès, angelai, požemių pasaulis - tai pragaras, kančių vieta. Bet ir žemëje veikia antgamtinès jègos: Dievas, angelai, Šètonas ir jo demonai, į žemę Viešpats ateis prikelti mirusiųjų etc. (Bultmann 1958a: 14-15). Bultmannas teigia, kad visa tai yra mitinis kalbejjimas. Pavienius Naujojo Testamento momentus galima nesunkiai pritaikyti anuometinei žydų Apoka- 
lipsės mitologijai ir gnostiniam išganymo mitui. O kadangi toks kalbejjimas yra mitologinis, tai šiuolaikiniam žmogui jis yra svetimas. Ar verta mums stengtis perimti praeities mitologini paveikslą?

Pasak Bultmanno, mitas turi būti interpretuojamas antropologiškai, t. y. egzistenciškai. Mite kalbama apie tas jègas, kurios pagrindžia žmogaus pasauli. Tokiu atveju teologijos uždavinys yra numitinti krikščionišką tiesos sakymą. Beprasmiška šiuolaikini krikščioni versti perimti mitologini Naujojo Testamento pasaulèvaizdi, nes toje mitologijoje nèra nieko specifiškai krikščioniško. Pasak Bultmanno, šiuolaikinis žmogus negali priimti biblinio pasaulio vaizdo, nes „neimanoma naudotis elektra ir radiju ar ligos atveju kreiptis pagalbos i i šiuolaikinę mediciną ir sykiu tikèti dvasių pasauliu bei Naujojo Testamento stebuklais" (Bultmann 1958: 10). Todèl Bultmannas siūlo toki kelią šiam konfliktui įveikti: mitologinis apvalkalas neišreiškia krikščioniškojo mokymo esmès - jis visuomet yra tik ano laikotarpio dvasią atitinkan- tis tam tikras būdas perteikti Gerają naujieną. Šiandien mitologinis mąstymas yra praeities reikalas, nes jis ivveiktas mokslinio mąstymo. Tad krikščionybės esmę, jos egzistencinį turinị, kerigma, paslèptą po mitologiniu apvalkalu, būtina išversti i šsiuolaikinę kalbą ir tokiu būdu racionaliai interpretuoti, kad ji nebeprieštarautų mokslinėms žinioms apie pasauli ir pati žmogų. Savo užduoti Bultmannas regi kaip sieki parodyti šiuolaikiniam žmogui, kas yra krikščionių religija: „Paaiškinti tai, kas yra krikščioniškas tikejjimas, man regisi, yra vienintelis, taip pat lemiamas dalykas, kuri gali padaryti teologija augančio pavojaus akivaizdoje" (Jaspers/Bultmann 1954: 61).

Taigi numitinimo programoje reikia išskirti pozityvų ir negatyvų aspektus: numitinima kaip pašalinimą grynai mitologinių vaizdinių, susijusių su archaika, kuri nebeaktuali šiuolaikiniam pasauliui, ir egzistencine interpretacija, atveriančią egzistencinę krikščionių tikejjimo prasmę, leidžiančią šiuolaikiniam žmogui suprasti save pati.

\section{KARLO JASPERSO NUMITINIMO KRITIKA}

Filosofas Karlas Jaspersas, panašiai kaip ir Bultmannas, kvietė modernizuoti krikščionybę, tačiau ị Bultmanno siūlomą numitinimo programą jis žvelgè nepatikliai. Prasidejjusi diskusija, tiesą sakant, niekuomet netapo tikru dialogu - neivvyko gyvas susitikimas ir diskusija, kada atidžiai izsiklausoma iz argumentus.

Jaspersas išdèstè prieštaravimus prieš numitinimo programą. Pirmiausia jam nepriimtinas pats šios idejjos metodologinis pamatas - Heideggerio egzistenci- nė filosofija. Jaspersas ją vertina šitaip: „Ši filosofija man atrodo dviprasmiška. Jis mąsto egzistencinę filosofiją remdamasis Kierkegaard'u, Lutheriu, Augustinu, tačiau tuo pat metu moksliškai fenomenologiškai ją objektyvuoja. Tačiau toks objektyvavimas visumą daro nerišlia, fenomenologiškai neutralia, šablonišką ir nepriimtiną žinojimo požiūriu, o sykiu filosofiškai neteisinga" (Jaspers/ Bultmann 1964: 12). Bultmannui Jaspersas priekaištauja, kad „mokslinę filoso- 
fiją jis supranta XIX amžiaus profesorių filosofijos (Professorenphilosophie ${ }^{2}$ ) ar Helenizmo epochos doksografijos prasme“ (Jaspers 1953: 1006).

Sykiu Jaspersas nepritaria teiginiui, esą šiuolaikinis mokslas suteikia žmogui tikra žinojimą apie jo kilmę bei vietą pasaulyje ir atsako i kitus egzistencinius klausimus. Jo nuomone, daugelis šiuolaikinių žmonių paprasčiausiai menkai nusimano apie mokslo laimèjimus. Dar daugiau - „tikejjimas absurdiškais dalykais šiandien yra nè kiek ne mažesnis, nei anksčiau“ (Jaspers 1964: 10). Jasperso manymu, pagrindinė Bultmanno klaida yra ta, kad jis nepagristai supriešino mitą ir mokslą, laikydamas, jog mokslas įveikè mitologinį mąstymą ir tuo būdu , atkerèjo“ pasauli. Jaspersas įsitikinęs, kad mitologinio mąstymo įveikti neįmanoma, kad jis būdingas kiekvienai žmonijos epochai, kad mūsų sąsaja su mitu niekuomet nesibaigia, todèl mito negalima ignoruoti. Anot Jasperso, „numitinimas yra beveik šventvagiškas žodis. Tai ne Apšvieta, o tuščias švietèjiškumas, tegebantis nuvertinti žodi mitas" (ten pat: 19).

Kyla klausimas, kodèl gi mitas Jaspersui yra toks svarbus. Pirmiausia mitas ji intriguoja tuo, kad mito tiesa nèra pažinimas, mito negalima redukuoti i sąvoką. Pagal jo apibrěžimą „mitas“ kalba ižvalgomis, kurios turi antgamtine reikšmę.

Sekant Jasperso argumentus prieš numitinima, idomu matyti paraleles su kai kurių vèlesnių autoriu pozicijomis, kurios patvirtina Jasperso požiūrị. Pavyzdžiui, vienas svarbiausių šiuolaikinių mito tyrinètoju Hansas Blumenbergas savo fundamentaliame veikale Arbeit am Mythos spejja, kad mitas yra reikalingas ne vadinamiesiems primityviems žmonèms, bet mums visiems (Blumenberg 1985: 3-4). Mums jo reikia tam, kad užkardytume tai, ką Blumenbergas ịvardija kaip "tikrovès absoliutizmą" - absoliutu tikrovès nedisponuojamuma, keliantį žmogui pirmapradi siaubą (ten pat: 7). Mat mūsų žinojimas visuomet yra tik dalinis, o tikrovės absoliutizmas yra totalus. Mokslinio pobūdžio žinių neužtenka, ir mums reikia šio to daugiau nei žiniu, kad galètume susidoroti su tikrovès absoliutizmu. Blumenbergas nepritaria Wilhelmo Nestle įtvirtintai formulei vom Mythos zum Logos, žyminčiai tariamą žmogiškojo pažinimo pažangą. Sykiu jis nepritaria ir isitikinimui, kad mokslinis racionalumas yra baigtinè būsena (ten pat: 49). Racionalumas ir mitas yra vienas nuo kito neatskiriami nuo pat istorijos pradžios iki dabar. Sykiu ironiška, kad mitizacija ivvyksta tada, kai darome skirtumą tarp mito ir racionalumo. Panašiai mano ir filosofas Odo Marquardas. Jis teigia, kad pats numitinimo procesas yra mitas (Marquard 1989: 89). Pats faktas, kad "mitas miré" tampa mitu, ir tai rodo savotišką mito nemirtingumą. Marquardui mitas yra tai, be ko tiesiog negalètume būti - mes jo negalime nusimesti tarsi kokio rūbo (ten pat: 91). "Mitinis nuogumas" (čia Marquardas daro aliuziją i Hanso Blumenbergo „nuogos tiesos" metaforos tyrimą) tiesiog neegzistuoja (plg. Blumenberg 2010: 40-51). Marquardas yra labai skeptiškas numitinimo ir ",mitinio striptizo“ atžvilgiu: kuo daugiau mito pašaliname, tuo, rodos, labiau jis priešinasi ir išlieka. Todèl mitinis nudizmas paprasčiausiai neimanomas. 
Bultmannas oponavo Jaspersui, prikišdamas, kad šis naiviai supranta opoziciją tarp archainès sąmonès žmogaus ir žmogus, kuris reprezentuoja Apšvietos ìtvirtintą mokslinę pasaulèžiūrą. Viename savo esè teologas skundžiasi, kad jo kritikai jo nesupranta: „Vis girdžiu priekaišta, esą numitinimas krikščionišką tikejjimą pavers filosofija. Šis priekaištas kyla iš to, kad numitinimą aš vadinu interpretacija, egzistencine interpretacija, ir iš to, kad aš vartoju sąvokas, išplètotas Martino Heideggerio egzistencinèje filosofijoje" (Bultmann 1958a: 45).

Atsakydamas Jaspersui, Bultmannas rašo: „kuo labiau gilinausi i jo samprotavimus, tuo sunkiau man darèsi jam atsakyti. Taip yra dèl to, kad vis aiškiau jaučiau, jog tie samprotavimai menkai išsitenka tikros komunikacijos, sokratiškai platoniško dialegesthai stiliaus ribose, jog tai greičiau yra žodžiai, ištarti ex cathedra" (Bultmann 1954: 415).

Iš tiesu, skaitant Jasperso tekstus, kuriuose jis kritikuoja Bultmanno numitinimo koncepcija, tarpais trikdo pernelyg kategoriškas šios kritikos tonas. Vis dèlto tenka pripažinti, kad diskutuodamas su Bultmannu, Jaspersas užčiuopè turbūt silpniausią numitinimo koncepcijos vie- tą - tai, jog Bultmanno numitinimo programos išeities taškas yra požiūris, kad krikščioniškas apreiškimas iš esmès skiriasi nuo mito. Jaspersas yra priešingos nuomonès: „Jeigu mitui priešinamas apreiškimas, tai toje priešpriešoje aš matau tik paties mitologiškumo viduje glūdinčią priešpriešą" (Jaspers/Bultmann 1954: 89). Todèl, anot Jasperso, numitinimo šalininkai, reikalaudami interpretuoti biblinius mitus, pašalinant mitinę kalbą, suduoda stiprų smūgi krikščioniškajam mokymui. Juk pats apreiškimas - tai ne kas kita kaip mitas, ir ,griaunantis numitinimo principas, vieną kartą pradètas, galiausiai sunaikins ir pati tikejjimą apreiškimu" (Jaspers 1964: 4). Jaspersas remiasi prielaidomis, kad mitas visada sudarè ir sudaro religinių vaizdinių esmę ir kad mito sugriovimas reikštų ir religijos sunaikinimą. Bultmanno siūlomas numitinimo metodas įsisąmoninti tikrą tikèjimą Jasperso manymu, ne tik filosofiškai nepajègus, bet ir praktiškai bevaisis, nes „Biblinè tiesa igyjama ne tyrinejjant, bet tik per tikèjimo praktiką" (Jaspers/Bultmann 1954: 34). Čia Jaspersas iž̌velgia analogiją tarp gydytojo ir dvasininko: abiem atvejais praktika turi pirmenybę prieš žinojima, kuris atlieka tik pagalbinį vaidmenį.

\section{JASPERSO ŠIFRŲ TEORIJA KAIP NUMITINIMO ALTERNATYVA}

Transcendencijos „šifrais“ Jaspersas vadina savitas, neobjektines transcendencijos „,apraiškas“, per kurias žmogus gali patirti transcendencija, tačiau patirti tik tada, kai jis išgyvena ypatingą egzistencini sukrètimą. Trečiame savo veikalo Philosophie tome, skirtame metafizikai, Jaspersas pabrèžia, kad transcenden- cija mums duota ne tiesiogiai, o tik per šifrus. Metafizika čia pasirodo kaip tú šifrų analizè. Jaspersas ieško filosofinių, teologiniu ir egzistenciniu prieigu prie transcendencijos, kelia klausimą - kas gali būti būties šifru ir koks turètų būti to šifro perskaitymas. Radikalus transcendencijos šifras yra išnykimas, istori- 
nės egzistencijos žlugimas, kuris savaip atveria žmogui transcendentinę tikrovę. Anot Jasperso, Jėzaus kaip transcendencijos šifro prasmè yra tokia: amžinajj išganymą žmogus pasiekia dèl to, kad aukojasi (arba pasiaukos ateityje), kaip taip padare Jėzus. Tikras biblinis tikejjimas gali būti paremtas tik žmogumi Jèzumi, suprantamu kaip žmogaus žlugimo šifras. Ši egzistencinio žlugimo tema i Jasperso filosofinę teologiją iveda eschatologinę problematiką.

Kalbant apie Jasperso „,̌ifro“ sampratą reikia atsižvelgti i jo suformuotą filosofinio tikejjimo sąvoka, kurios branduolys ir yra daugiareikšmè transcendencijos sąvoka. Jaspersas skiria transcendencija tikraja šio žodžio prasme ir netikra, universalia transcendencija. Transcendencija Jaspersas nusako kaip tai, kas pranoksta visus pasaulio objektus, kuriuos galima suvokti kaip objektišką tikrovę. Kadangi bet koks pažinimas, anot Jasperso, yra objektiškas, tai transcendencijos pažinti neimanoma (Jaspers 1958a: 37).

Jaspersas teigia, kad transcendencija daugiau nebèra tai, kas yra "viršuje“, ji yra tai, „,kas aplinkui mus“, todèl jai žymèti jis siūlo „aprèpties“ sąvoką (Jaspers 1932: 640).

Apreptis yra universali transcendencija. Jei transcendavimu laikysime bet kokio daiktiškumo peržengimą, tai transcendencija galėsime pavadinti „,bet koki aprépties egzistavimo būdą" (Jaspers 1958b: 109). Visos aprépties rūšys esamybė, sąmonė apskritai, dvasia, egzistencija, pasaulis ir transcendencija priklauso transcendencijos sferai. Visi būties pasaulyje būdai - transcendencijos kalbos medžiaga. Tačiau „tikrąja transcendencija" Jaspersas vadina tik absoliučią aprèpti, „,visos aprèpties aprèptic. Tai visu „transcendencijų transcendencija", ją taip pat galima pavadinti „būtimi, autentiška tikrove, dievybe, Dievu“ (ten pat: 109, 111).

Jaspersas pabrèžia, jog tarp transcendencijos ir egzistencijos esama esminio ryšio. Pasaulis tampa suprantamas žmogui tik per jo asmenini buvima, egzistenciją. Transcendencija yra ne kas kita, kaip tai, kas suteikia egzistencijai galutini pamatą: „Aš esu egzistencija tik vienovejje su žinojimu transcendencijos kaip jègos, dèl kurios esu savimi“ (ten pat: 110).

Nesunku pastebèti, kad trys pagrindiniai "aprèpties" būdai - pasaulis, egzistencija ir transcendencija - atitinka teistinès tradicijos palaikomą trichotominę tikrovès struktūrą: daiktu pasaulis, organinis / nedaiktiškas pasaulis ir absoliutas / nedaiktiškas dievas. Tačiau Jasperso transcendencija - tai deus absconditus: ji negali būti pažinta ir išsakyta. Čia Jaspersas pats susiduria su religijos kalbos problema, bandymu išspręsti kurią galima laikyti ir Bultmanno numitinimo projektą. Kritikuodamas Bultmanną, Jaspersas laikosi požiūrio, kad religijos kalbos problemą galima išspręsti ne pašalinant iš kalbos mito elementus, o pasitelkiant transcendencijos šifrus. Jo išeities taškas yra teiginys, kad transcendencija neaptinkama jokiuose reiškiniuose. Ji yra apréptis, kuri, kitaip nei žmogus ir būtis pasaulyje, neturi jokio „daiktiško" pavidalo (ten pat: 639). Vadinasi, transcendenciją galima mąstyti tik netiesiogiai - atpažistant ją "daiktiškuose" pavidaluose. Daiktai pasaulyje tampa transcendencijos „šifrų“ kalba.

Jaspersas skiria tikrovès reiškinius, egzistencijos ženklus ir transcendencijos 
šifrus. „Būtis pasaulyje“ su mumis kalba per "daiktiškus" tikrovés pavidalus ir šitai sąlygoja mūsų mąstymą bei aprèžia kalbos galimybes bandant nusakyti egzistenciją ir transcendenciją. Jaspersas pabrèžia, kad „šifrai niekuomet nèra pačios transcendencijos tikrové, o tik jos galima kalba“" (Jaspers 1962: 155).

Šifrus Jaspersas nusako kaip „reikšmes, kuriu neįmanoma atskleisti nurodant tai, ką jos reiškia. Jos šį tą reiškia, tačiau tai, ką jos reiškia, nèra Kas nors. Tai, ką jos reiškia, yra tik šifruose" (Jaspers 1970: 132). Tuo šifrai skiriasi nuo ženklų. Kita vertus, jie skiriasi ir nuo simbolių: „,Simbolis reiškia buvimą kažko „regimo", kame nepertraukiamai susiję reikšmè ir tai, kas žymima. Tai, kas simbolizuojama, yra tik pačiame simbolyje. Simbolis - tai ko nors kito reprezentantas. Šifras, kitaip nei simbolis, yra transcendencijos „kalba“ (Jaspers 1962: 157).

Jaspersas išskiria tris šifro kalbas: pirmapradę patirti, mitą ir apreiškimą bei filosofinę spekuliaciją. „Pirmapradè patirtis", "netiesioginè transcendencijos kalba" - tai Jaspersas vadina "pirmaja kalba“. Joje nieko negalima žinoti apie
Dievą bendraja forma. „Pirmapradès patirties" perdavimą regimomis formomis Jaspersas vadina "antraja kalba“: joje pirmine kalba objektyvuojama mituose ir apreiškime. Ir galiausiai filosofinès spekuliacijos - tai "trečioji kalba“. Spekuliatyvios kalbos pavyzdys yra metafizinès sistemos, o pirmiausia - jose aptinkami Dievo būties įrodymai, svarstymai apie kuriuos (jeigu tie svarstymai yra persmelkti vidinių išgyvenimų) gali tapti keliu i transcendenciją. Visos trys kalbos - transcendencijos šifrai, kur antra ir trečia kalba nušviečia pirmosios turini ir daro imanomą jos perdavimą kitiems (ten pat: 129-133). Anot Jasperso, norint išsaugoti religijos turini, svarbu suprasti apreiškimą ne kaip realų ìvyki, kuri galima būtu empiriškai patikrinti, bet būtent kaip šifrą.

Jaspersas, atverdamas šifrų esmę ir jų reikšmę siekiant transcendencijos, vèl nurodo "filosofinio tikëjimo" ir tikejjimo, besiremiančio apreiškimu, skirtumus: „Filosofiniam tikèjimui visi aprépties būdai, o ypač egzistencijos santykis su transcendencija, yra įmanomi be apreiškimo" (Jaspers 1962: 166).

\section{IŠVADOS}

Gali atrodyti, kad Jaspersas savo teiginiais prieštarauja pats sau. Tačiau kaip tik šis prieštaravimas sau pačiam yra savotiškas „šifras“, rodantis, kad turime reikalą su postsekuliariu mąstymu, suvokiančiu, kad tik šitaip ir įmanoma kalbèti apie transcendenciją.

Šiuo požiūriu galima izžvelgti postsekuliaraus mąstymo panašumą i apofatinès teologijos tradicija, kurios kontekste išsitenka ir Bultmanno numitinimo pro- grama. Iš tiesų juk pagrindinis Bultmanno tikslas yra interpretuoti Naujojo Testamento tekstą ne kaip istorini pasakojimą kurį šiuolaikinis žmogus gali suvokti tik kaip informaciją apie prieš du tūkstančius metu vykusius įvykius, o kaip egzistenciškai išgyvenamą sąsają su transcendencija. Mitai postsekuliarybès salygomis nepraranda savo aktualumo, o veikiau priešingai - jie tampa dar svarbesni nei anksčiau. 


\section{Literatūra}

Cox Harvey. 2013. The Secular City. Secularization and Urbanization in Theological Perspective. Princeton an Oxford: Princeton University Press.

Blumenberg Hans. 2010. Paradigms for a Metaphorology. NewYork: Cornell University Press.

Blumenberg Hans. 1985. Work on Myth. Massachusetts: The MIT Press.

Bultmann Rudolf. 1958a. Jesus Christ and Mythology. New York: Charles Scribner's Sons.

Bultmann Rudolf. 1954. Zur Frage der Entmythologisierung. Antwort an Karl Jaspers. Merkur, Mai, 8. Jahrgang, Heft 75.

Bultmann Rudolf. 1958. Glauben und Verstehen. Bd.2, Tübingen: J.C.B. Mohr.

Jaspers Karl, Bultmann Rudolf. 1954. Die Frage der Entmythologisierung. München: Piper.

Jaspers Karl. 1932. Philosophie. 3 Bände (I. Philosophische Weltorientierung; II. Existenzerhellung; III. Metaphysik). Berlin: Springer. Bd.3.

Jaspers Karl. Wahrheit und Unheil der Bultmann-

\section{Nuorodos}

${ }^{1}$ Mokslinis tyrimas finansuotas Europos socialinio fondo lëšomis pagal priemonès Nr. 09.3.3LMT-K-712 veiklą "Mokslininkų kvalifikacijos tobulinimas vykdant aukšto lygio MTEP projektus". schen Entmythologiesierung, Merkur, November 1953, 7. Jahrgang, Heft 69:1001-1022.

Jaspers Karl. 1958a. Philosophie und die Welt. Reden und Aufsätze. München: Piper.

Jaspers Karl. 1962. Der philosophische Glaube angesichts der Offenbarung. München: Piper.

Jaspers Karl. 1958b. Von der Wahrheit. München: Piper.

Jaspers Karl. 1964. Umgang mit dem Mythos. Merkur, Januar 1964, 18. Jahrgang, Heft 191: 1-13.

Jaspers Karl. 1970. Chiffren der Transzendenz. Eine Vorlesung aus dem Jahr 1961. München: Piper.

Marquard Odo. 1989. Farewell to Matters of Principal. Philosophical Studies. Oxford: Oxford University Press.

Taylor Charles. 2007. A Secular Age. Cambridge, Massachusetts, and London: Harvard University Press.

The Heidegger - Jaspers Correspondence (1920-1963). 2003. New York: Humanity Books.

${ }^{2}$ Prieš tokią filosofijos sampratą Jaspersas nepaliaujamai kovojo. Plg.: Jasperso ir Heideggerio korespondenciją (The Heidegger - Jaspers Correspondence (1920-1963). 2003. New York: Humanity Books). 